$10-2016$

\title{
Forgotten and Concealed: The Emblematic Cases of the Assyrian and Romani Genocides
}

Riccardo Armillei

Deakin University

Nikki Marczak

Australian Institute for Holocaust and Genocide Studies

Panayiotis Diamadis

Australian Institute for Holocaust and Genocide Studies

Follow this and additional works at: https://digitalcommons.usf.edu/gsp

\section{Recommended Citation}

Armillei, Riccardo; Marczak, Nikki; and Diamadis, Panayiotis (2016) "Forgotten and Concealed: The Emblematic Cases of the Assyrian and Romani Genocides," Genocide Studies and Prevention: An International Journal: Vol. 10: Iss. 2: 98-120.

DOI:

http://dx.doi.org/10.5038/1911-9933.10.2.1404

Available at: https://digitalcommons.usf.edu/gsp/vol10/iss2/9

This Articles is brought to you for free and open access by the Open Access Journals at Digital Commons @ University of South Florida. It has been accepted for inclusion in Genocide Studies and Prevention: An International Journal by an authorized editor of Digital Commons @ University of South Florida. For more information, please contact digitalcommons@usf.edu. 


\title{
Forgotten and Concealed: The Emblematic Cases of the Assyrian and Romani Genocides
}

\author{
Riccardo Armillei \\ Deakin University \\ Geelong, Victoria, Australia \\ Nikki Marczak \\ Australian Institute for Holocaust and Genocide Studies \\ Panayiotis Diamadis \\ Australian Institute for Holocaust and Genocide Studies
}

\begin{abstract}
By exploring how the Assyrian and Romani genocides came to be forgotten in official history and collective memory, this paper takes a step towards redress for years of inadvertent neglect and deliberate concealment. In addressing the roles played by scholars and nations, and the effect of international law and government policy, it notes the inaccessibility of evidence, combined with a narrow application of definitions of victim groups, and a focus on written proof of perpetrator intent. Continuing persecution of survivors in the aftermath of the genocides, and government actions to erase the genocides from history, are common to both cases. The dimension of a comparative analysis between two emblematic "hidden" genocides shows that there are many similarities in the process of forgetting that occurred in their respective aftermaths. Developing an understanding of how these genocides came to be ignored and forgotten may provide a foundation for genuine acknowledgment and redress.
\end{abstract}

Keywords: Romani/Roma, Assyrians/Assyria, genocide, hiddenness, concealment, forgotten

\section{Introduction}

Seventy years after the liberation of Auschwitz, Romani peoples are still struggling to have their tragic experiences during the Second World War acknowledged. Only a few survivors are still alive. Hermann Höllenreiner is one such survivor, and remains deeply troubled by the unlearned lessons of what he calls the "forgotten genocide" - the systematic liquidation of Europe's Romani population. ${ }^{1}$ Likewise, descendants of victims of the Assyrian Genocide experience the hidden nature of their history as an added insult; as compounding the trauma of the genocide itself. This experience is encapsulated in the words of Joseph Zaya, born in the Hakkari region of south-east Anatolia, who shortly before he passed away at the age of one hundred stated that this genocide "is something that we Assyrians should never forget, and the world should not forget it, either." 2

The factors contributing to the hiddenness of a particular genocide are often made up of an interrelated web of political, economic, religious and geostrategic interests; and are the result of a combination of actions by various parties. This paper will examine why some genocides are ignored or fade into oblivion, by looking at the cases of the Assyrian Genocide, which occurred alongside the Armenian Genocide during the First World War, and the Romani Genocide during the Nazi-Fascist era in Europe. These emblematic examples illustrate how and why some genocides are studied, reported, and officially commemorated, while others are ignored and their victims forgotten. As René Lemarchand writes in his edited volume, Forgotten Genocides, "the systematic eradication of tens if not hundreds of thousands of Assyrians receives little or no attention. Again, consider the marginal attention paid to the martyrdom of the Gypsy victims of the Holocaust."3

The phenomenon of hidden or forgotten genocides has received some attention in recent years, and two texts in particular have informed the analysis in this paper-Lemarchand's abovementioned Forgotten Genocides; and Hidden Genocides: Power, Knowledge, Memory, edited by

\footnotetext{
${ }^{1}$ Anthony Faiola, Ruth Eglash and Michelle Boorstein, "The Voices of Auschwitz," The Washington Post, January 23, 2015, accessed March 1, 2016, http://www.washingtonpost.com/sf/world/2015/01/23/with-fewer-voices-auschwitzsurvivors-speak/; Laura Shepard Townsend, "The Holocaust's Forgotten Roma Victims," MJCIMAGEWORKS, September 14, 2014, accessed March 1, 2016, http://mjcimageworks.com/blog/the-holocausts-forgotten-roma-victims/.

2 Assyrian International News Agency, "99 Years of Turkish Genocide," AINA, April 23, 2014, accessed March 13, 2016, http://www.aina.org/releases/20140423134125.htm.

${ }^{3}$ René Lemarchand, Forgotten Genocides: Oblivion, Denial, and Memory (Philadelphia: University of Pennsylvania Press, 2013), 11.
}

Riccardo Armillei, Nikki Marczak, and Panayiotis Diamadis, "Forgotten and Concealed: The Emblematic Cases of the Assyrian and Romani Genocides" Genocide Studies and Prevention 10, 2 (2016): 98-120. ๑2016 Genocide Studies and Prevention. 
Alexander Laban Hinton, Thomas La Pointe and Douglas Irvin-Erickson. Both collections present a range of case studies and analyses, and the latter identifies a canon of genocide cases which "remain exemplary, first and foremost the Holocaust."4 The core of recognized genocides includes those in Rwanda, Bosnia, Cambodia and Darfur, those of Indigenous peoples broadly, and the Armenian Genocide, which has gained attention in recent years and which is now also included in the triad of core genocides along with the Holocaust and Rwandan genocide. Those genocides which have engendered less recognition, constitute what has been referred to as the "second circle", "periphery", and finally "forgotten" genocides, ${ }^{5}$ encompassing cases ranging from Bangladesh, Kosovo and the Ukrainian famine, to East Timor, Burundi and the Assyrian and Greek genocides. It is unclear where in this structure sit the many non-Jewish victims of the Nazis and their Axis allies, primarily Romani peoples but also Jehovah's Witnesses, homosexuals and other categories of people considered asocial.

This paper presents a comparative analysis of the Romani and Assyrian experiences, addressing the roles played by scholars and nations, and the effect of international law and government policy, in either blocking out or including particular events in collective memories and official history. A comparative analysis between the Romani and Assyrian cases can help to highlight the interplay between causes, and identify patterns that can lead to both unintentional forgetting and deliberate concealment.

This paper also notes the influence of issues internal to the victim communities, such as a cultural disinclination to record events in writing, resulting in a lack of survivor testimony, ${ }^{6}$ and in both cases, internal divisions which have prevented a unified voice to advocate the cause of recognition. Indeed, in consultations with Assyrian community representatives, the absence of a self-governed, autonomous nation-state is sometimes cited as a reason for the lack of power to drive recognition efforts, and this factor in itself would be worthy of a more detailed study. ${ }^{7}$

The most significant factors have been located outside the control of the communities themselves. Political motivations and the desire to consolidate national identities lie behind how history is written and how genocides are remembered. It may be a cliché that history is written by the victors, however the collective memory of a population is very often intentionally built by removing certain aspects and emphasizing others, creating a narrative that benefits that particular group. ${ }^{8}$ In the construction of historical narratives after both world wars, nations strove to create clear dichotomies between perpetrators and rescuers, or perpetrators and victims, with no room for complex analysis or acknowledgement of those countries which may have played simultaneous and often paradoxical roles (for instance, simplistic postwar narratives allowed especially non-Axis countries to conceal their own persecution of Romanies before, during and indeed after the war.)

\footnotetext{
${ }^{4}$ Alexander Laban Hinton, Thomas LaPointe, and Douglas Irvin-Erickson, eds., Hidden Genocides: Power, Knowledge, Memory (New Brunswick: Rutgers University Press, 2013), 5.

${ }^{5}$ Ibid, 6.

${ }^{6}$ Ian Hancock, "Responses to the Porrajmos: The Romani Holocaust," in Is the Holocaust Unique?, ed. Alan Rosenbaum (Boulder: The Westview Press, 2009), 138; Andrea Boscoboinik, "Challenging Borders and Constructing Boundaries: An Analysis of Roma Political Processes," in Identity Politics: Histories, Regions and Borderlands, eds. Vytis Ciubrinskas and Rimanta Sliuzinskas (Klaipeda: Klaipeda University Press, 2009), 187; Panayiotis Diamadis, “Controversies Around Governmental and Parliamentary Recognition of the Armenian, Hellenic, and Assyrian Genocides," The AHIF Policy Journal 7 (Spring 2016), accessed August 3, 2016, http://ahiworld.org/AHIFpolicyjournal/pdfs/ Volume7Spring/03diamadis.pdf; Hannibal Travis, "The Assyrian Genocide: A Tale of Oblivion and Denial" in Forgotten Genocides: Oblivion, Denial, and Memory, ed. René Lemarchand (Philadelphia: University of Pennsylvania Press, 2011).

${ }^{7}$ Many Assyrians advocate the establishment of a national homeland in the Nineveh region of Iraq, to which they are indigenous. In the Romani case, the idea of a nation-state is complicated by the fact that Romanies are not a landbased group, and opinions differ within Romani communities as to how their rights should be acknowledged and enshrined in policy or legislation; see Mirga, Andrzej, and Nicolae Gheorghe, "The Roma in the Twenty-First Century: A Policy," Project on Ethnic Relations, 1997, accessed August 3, 2016, http://www.per-usa.org/1997-2007/21st c.htm.

${ }^{8}$ For detailed theoretical analyses of social and collective memory, see e.g., Maurice Halbwachs, The Collective Memory, trans. F.J. Didder Jr. and V. Yazdi Ditter (New York: Harper and Row, 1980); Walter Benjamin, "Theses on the Philosophy of History," in Illuminations, ed. Hannah Arendt (London: New Left Books, 1973), 257-258; Helmut König, “Paradoxes of Memory," Eurozine, April 8, 2011, accessed August 3, 2016, http://www.eurozine.com/articles/ article 2011-08-04-koenig-en.html.
} 
The inaccessibility of documentation-records officially withheld by authorities or information presenting in wide range of languages-has also hindered academic research. ${ }^{9}$ Other issues relate to methods of implementation of the genocides, exacerbated by narrow academic and legal interpretations of the concept of genocide. For example, an intentionalist view of genocide in early historiography (that is, a view that genocide is the result of a central policy or decision by government, and recorded in writing) excluded the massacres of Romani peoples, which were often haphazard and locally-initiated, from mainstream definitions of genocide. Much official Ottoman documentation refers explicitly to the Armenian community, ${ }^{10}$ and although Assyrians were often directly targeted, or swept up in massacres of Armenians, clear proof is sometimes concealed behind the wording of Turkish documents.

Further, continuing prejudiceagainst thevictimsin theimmediateandlonger-term post-genocide environment, suppressionofinformationand nationalmythmaking, and consciousgovernmentefforts to muddy the identity of victims, can have profound effects on how genocides are written into, or omitted from, official histories. For example, as modern nation-states were created in the aftermath of the First World War, their new governments embedded the denial of Assyrian history by denying even the identity of Assyrians as a group. Forced to officially identify as members of other communities, the very existence of a group known as Assyrians was officially extinguished. ${ }^{11}$

Finally, ongoing discrimination meant that the survivors of genocide were not only deprived of acknowledgement of their suffering, but even blamed for bringing it on themselves. Since Romani peoples were imprisoned in camps based on their categorization as a social group with "criminal tendencies," their treatment during the war was considered to have been justified, and they were subsequently excluded from commemorations, memorialization and reparations processes. In fact, because they were believed to have been targeted as a social group, they have been excluded from legal recognition under the United Nations Convention on the Prevention and Punishment of the Crime of Genocide, which specifies that genocide can be committed solely against national, ethnic, racial or religious groups. ${ }^{12}$ For these and other reasons to be explored further in this paper, certain genocides of the twentieth century have been relegated to the footnotes of history.

Germany's wholehearted admission of guilt for the Jewish Holocaust has contributed to widespread memorialization and compensation, but this admission has only recently extended to other groups of victims. The Nazi genocide of Europe's Jews during the Second World War remains the most studied and publicly known genocide; in contrast, the attacks on Romani communities, and the ideologies that triggered them, remain relatively forgotten in academic literature and public consciousness. Today, the Assyrian and Armenian communities recognize and commemorate each other's history of genocide by the Ottoman and Republican Turkish authorities, ${ }^{13}$ but broader awareness of the Assyrian experience pales in comparison. Official Turkish denial of both genocides continues to this day, though global recognition of the Armenian experience has increased over recent years. For the Assyrian community, however, the hiddenness of its history represents an additional layer of denial.

The analysis in this paper is based on existing research by leading scholars of the Romani and Assyrian genocides, including Racho Donef, Hannibal Travis, David Gaunt, Nicholas AlJeloo, Ian Hancock and Michael Stewart, ${ }^{14}$ while also referring to the authors' own research.

\footnotetext{
${ }^{9}$ Hannibal Travis, "'Native Christians Massacred': The Ottoman Genocide of the Assyrians during World War I," Genocide Studies and Prevention 1, no. 3 (2006), 135.

${ }^{10}$ Official documentation often refers to the "Ermeni milliyet", which has been mistranslated as referring only to the Armenian community. It also referred to the non-Canonical Orthodox Christian community.

${ }^{11}$ Hannibal Travis, "The Assyrian Genocide: A Tale of Oblivion and Denial," in Forgotten Genocides: Oblivion, Denial, and Memory, ed. Rene Lemarchand (Philadelphia: University of Pennsylvania Press, 2013), 133.

${ }^{12}$ Michael Stewart, "The Gypsy Problem: An Invisible Genocide," in Forgotten Genocides: Oblivion, Denial, and Memory, ed. Rene Lemarchand (Philadelphia: University of Pennsylvania Press, 2013), 140.

${ }^{13}$ Assyrian Universal Alliance, "100 Years of Genocide, The Assyrian Nation reflects," Assyrian Universal Alliance, August 5, 2015, accessed March 5, 2016, http://aua.net.au/wp-content/uploads/2015/08/Media-Release-for-CentennialCommemoration.pdf.

${ }^{14}$ Particularly, see e.g. Racho Donef, Massacres and Deportation of Assyrians in Northern Mesopotamia: Ethnic Cleansing by Turkey 1924-1925 (Stockholm: Nsibin, 2009); Travis, "The Assyrian Genocide"; Hannibal Travis, "Constructing the
} 
The authors carried out fieldwork in Italy and Australia on the history of the Romanies, and the views of both Romani and Assyrian representatives were taken into account. While examining the case studies, this paper provides some background on the two communities, their history and culture, and experiences of persecution in the lead up to the two respective genocides. A section on the genocides themselves describes the ideological motivations and outlines how each community was targeted for elimination. It argues that in the aftermath of the genocides, deliberate efforts were made by governments to prevent any recognition of the genocides, and to blur the identity of the victim groups so as to avoid acknowledgement of their losses. Minimal scholarly attention, a lack of public commemoration, and limitations of the legal definition of genocide, represent some of the obstacles that the Romani and Assyrian communities continue to face as they seek recognition of their communities' respective historical and contemporary experiences of genocide and prejudice.

This article presents a new dimension of comparative analysis between the Romani and Assyrian genocides. The process of highlighting factors that are common to both has identified patterns in the development of the hiddenness of certain genocides. An awareness of these factors may help in the pursuit of recognition and redress.

\section{Theoretical Issues and Debates Concerning 'Hidden Genocides'}

Both the Assyrian and Romanigenocides have been primarily viewed, to theextent that they have been studied atall, throughthelens of othergenocides, partly theresultofeach havingoccurred concurrently to another genocide. Ian Hancock argues that recognition of each case should be pursued "in its own context, and not as a corollary to that of another people." ${ }^{15}$ While Hancock points out the value of exploring the history of each genocide as a singular event, comparative analyses can also be beneficial. Comparative analyses can become problematic however, when one genocide is always used as the lens for another, to the extent that one is subsumed or obscured by the other.

In genocide historiography, the Nazi Holocaust of European Jewry is recognized as the paradigmatic genocide, where "other genocides are often seen and interpreted through the lens of our understanding about the Holocaust".${ }^{16}$ Indeed, there are important ways that the Holocaust can form a useful foundation, not least because of the enormous evidence base it provides to the study of genocide. Holocaust scholarship has developed theoretical frameworks for critical examination of all other cases of genocide, and the wealth of evidence and analysis in relation to the Holocaust provides a strong basis for studying other genocidal atrocities.

One of the unforeseen effects of the extensive attention on the genocide of the Jews, however, is that the Romani Genocide has been viewed exclusively in relation to the Holocaust. In practice, this has led to the creation of a neat distinction between a sort of "Upper-Case Holocaust" and a "lower-case holocaust." ${ }^{17}$ The experience of the Romanies has remained on the periphery of genocide scholarship and is hardly ever analyzed as a case of genocide in its own right, despite research suggesting that "together with Jews, the Romani victims were the only ethnic/racial population selected for total annihilation."18

'Armenian Genocide': How Scholars Unremembered the Assyrian and Greek Genocides in the Ottoman Empire," in Hidden Genocides: Power, Knowledge, Memory, eds. Alexander Laban Hinton, Thomas La Pointe, and Douglas IrvinErickson (New Brunswick: Rutgers University Press, 2014); David Gaunt, Massacres, Resistance, Protectors: MuslimChristian Relations in Eastern Anatolia during World War I (Piscataway: Gorgias Press, 2006); Stewart, "The Gypsy Problem"; Hancock, "Responses to the Porrajmos"; Nicholas Al-Jeloo, "Who are the Assyrians?", Conference Paper at The Assyrian Australian Academic Society, Sydney, Australia, July 2, 2000; Nicholas Al-Jeloo, "Assyrians: Between Homeland and Diaspora", Conference Paper at Assyrian American Cultural Organization of Arizona, Arizona State University-West Campus, September 7, 2013.

${ }^{15}$ Ian Hancock, "Romanies and the Holocaust: A Re-evaluation and an Overview," in The Historiography of the Holocaust, ed. Dan Stone, (New York: Palgrave-Macmillan, 2004), 395.

${ }^{16}$ Task Force for International Cooperation on Holocaust Education, Remembrance, and Research, "2010 Education Working Group Paper on the Holocaust and Other Genocides," United Nations, 2010, accessed March 16, 2016, http:// www.un.org/en/holocaustremembrance/EM/partners\%20materials/EWG Holocaust and Other Genocides.pdf.

${ }^{17}$ Hancock, “Downplaying the Porrajmos," 82.

${ }^{18}$ János Bársony and Ágnes Daróczi, eds., Pharrajimos: The Fate of the Roma during the Holocaust (New York: International Debate Education Association Press, 2008), 2. 
Likewise, the Armenian Genocide is the ultimate early model of a modern, bureaucratic, systematic genocide of a minority group viewed as a national, ethnic and religious threat. The atrocities against Assyrians that began just prior, in 1914, tend to be viewed, only and always, comparatively through the lens of the Armenian Genocide. There are important distinctions however, between the Assyrian and Armenian examples. The national, ethnic, cultural and linguistic, demographic and religious motivators that influenced the Armenian Genocide should not be neglected in the process of recognizing the Assyrian tragedy. However, it is fair to say that the Assyrian Genocide has been largely overshadowed by study of the Armenian experience.

Debate remains as to whether the Holocaust's status as paradigmatic example nurtures or hinders scholarship and memorialization of other genocides..$^{19}$ In recent years, some genocide scholars have claimed that particular victim communities have highlighted their own suffering while deliberately shutting out attention and empathy for other communities. Yair Auron has criticized the repression of experiences of non-Jewish victims of the Nazis, ${ }^{20}$ while Dirk Moses has written on the phenomenon of competitiveness within genocide memorialization and historiography, arguing that groups seek to assert the uniqueness of their own experience while diminishing the suffering of others. Moses' article about the development of the Canadian Museum of Human Rights claims that some communities view the memorialization of the genocide of another group as a direct threat to the memory of their own experience, and his application of Emile Durkheim's theory of the sacred versus the profane has shown how one's own history of genocide may be felt as somehow special ("events that are loved, venerated, or dreaded, and that are superior in dignity to the ordinary world of the profane" ${ }^{\prime 21}$ relative to others' experiences of genocide. Hannibal Travis has alleged that some scholars of the Armenian Genocide intentionally omitted information about the Assyrian Genocide in the construction of Armenian Genocide historical narratives. ${ }^{22}$ All of these theories are highly contested. For instance, in his book review, Uğur Ümit Üngör rejects Travis' claim about Armenian Genocide scholars, ${ }^{23}$ while Dina Porat at Yad Vashem, the World Holocaust Remembrance Center, "vehemently rejects" Auron's allegations. ${ }^{24}$

The authors of this paper do not believe it is helpful to blame one victim community for eclipsing the experiences of another; but rather seek to focus on the interplay of various factors in the development of each genocide. Shedding light on less well-known genocides is not intended to equate these with their better-known counterparts. In fact, the process of comparative analysis actually emphasizes distinguishing features as well as parallels, allowing a deeper understanding of the manifold ways that genocides are devised and implemented. It follows that exploring the ways in which the Assyrian and Romani histories have been ignored or forgotten, and bringing their genocides to light, in no way diminishes the experiences of the Ottoman Armenians or the Jewish communities of Europe.

\section{Background}

The Assyrian Community

As the indigenous people of Bet-Nahrain ("the Land Between the Rivers"), the Assyrians have inhabited the upper reaches of the Tigris and Euphrates River valley systems since the beginning of recorded history. Perhaps as early as the 2400s BCE, Assyrians had formed states in Mesopotamia, with their last great state falling in $612 \mathrm{BCE} .{ }^{25}$ King Abgar of Edessa was the first ruler to convert to

\footnotetext{
${ }^{19}$ For example, A. Dirk Moses, “The Canadian Museum for Human Rights: the 'Uniqueness of the Holocaust' and the Question of Genocide," Journal of Genocide Research 14, no. 2 (2012).

${ }^{20}$ Ofer Aderet, "Genocide Scholar Blasts Israel's ‘Racist' Teaching of the Holocaust”, Haaretz, January 27, 2016, accessed March 13, 2016, http://www.haaretz.com/israel-news/.premium-1.699749.

${ }^{21}$ A. Dirk Moses, “Conceptual Blockages and Definitional Dilemmas in the 'Racial Century': Genocides of Indigenous Peoples and the Holocaust," Patterns of Prejudice 36, no. 4 (2002), 11.

22 Travis, "Constructing the 'Armenian Genocide'," 172.

${ }^{23}$ Uğur Ümit Üngör, "Book review: 'Hidden Genocides: Power, Knowledge, Memory'," Genocide Studies and Prevention: An International Journal 8, no. 3 (2014), 101-102.

${ }^{24}$ Aderet, "Genocide Scholar Blasts," para 5.

${ }^{25}$ Lawrence Cunningham and John Reich, Culture and Values: A Survey of the Humanities (Boston: Cengage Learning, 2009), 10.
} 
Christianity, taking his subjects with him. The geostrategic importance of the Assyrian homeland astride key trade and travel routes made the community susceptible to repeated invasions and conquests by foreign forces including the Eastern Romans (erroneously named Byzantines), ${ }^{26}$ Iranian Persians, and Mongols.

The development of a modern, national identity amongst the Assyrians of the Ottoman Empire inevitably clashed with the Turkish and Kurdish nationalisms emerging in the early twentieth century. They came to be viewed, like the Armenians, as a threat to the longed-for ethnic and religious homogeneity of the Turkish state. By January 1914, six years after the coup d'état that brought the Committee for Union and Progress (CUP) to power, the long-standing enmity between Muslim Turks and indigenous Christian populations was at the point of exploding.

The Ottoman Empire's milliyet system classified personal identity by the house of worship an individual attended. ${ }^{27}$ The development of Assyrian Christianity ${ }^{28}$ led to a split from the Orthodox Patriarch in Constantinople, and Assyrians were subsequently classified as being part of the Ermeni milliyet, ${ }^{29}$ with the Armenian Patriarchs of Constantinople and Cilicia being responsible for their good behavior. It is clear that the CUP (also known as the Young Turks), despite expressing a secular agenda, was in no hurry to abolish the existing religiously-based social system, reflected in the resolutions adopted by the 1910 CUP Congress in Thessalonike (Salonika):

Musulmans generally should retain their arms, and where they are in a minority arms should be distributed to them by the authorities. ... Emigration from the Caucasus and Turkestan must be encouraged, land provided for the immigrants, and the Christians prevented from purchasing property. ... Turkey was essentially a Moslem country, and Moslem ideas and influence must preponderate. All other religious propaganda must be suppressed, as no reliance could be placed on Christians, who were always working for the downfall of the new regime. ... Sooner or later the complete Ottomanization of all Turkish subjects must be effected, but it was becoming clear that this could never be achieved by persuasion, and recourse must be had to force of arms. ${ }^{30}$

Moreover, genocidal language became increasingly common, laying the groundwork for the broader acceptance of massacre and deportation, with one of CUP's chief ideologues, Dr. Behaeddin Sakir, stating in 1911, "The nations that remain from the old times in our empire are akin to foreign and harmful weeds that must be uprooted." 31

\section{Romani Peoples}

The Romani ${ }^{32}$ population, likely originating from the north-west of India somewhere between the fifth and the tenth centuries ${ }^{33}$ comprises a multitude of sub-groups, scattered across all continents. ${ }^{34}$ The community first appeared in Europe under the Byzantine Empire, around the tenth century $\mathrm{AD}$ and were regarded as "outcasts, intruders, and threats, probably because of their dark skin,

\footnotetext{
${ }^{26}$ Fergus Millar, A Greek Roman Empire: Power and Belief under Theodosius II (408-450) (Berkeley: University of California Press, 2006), 15.

${ }^{27}$ Abdulaziz Sachedina, The Islamic Roots of Democratic Pluralism (New York: Oxford University Press, 2000).

${ }^{28}$ For additional analysis concerning religious developments within the Assyrian community, see Al-Jeloo, "Who are the Assyrians?" and Al-Jeloo, "Assyrians: Between Homeland and Diaspora".

${ }^{29}$ Kent F. Schull, "Difference during the Second Constitutional period," in Religion, Ethnicity and Contested Nationhood in the Former Ottoman Space, ed. Jørgen S. Nielsen (Leiden: Brill, 2012), 79.

30 "The Salonika Congress; The Young Turks and their Programme," The Times (London) October 3, 1911, 3.

${ }^{31}$ Ibid., 3.

${ }^{32}$ In this paper, we refer to "Romanies/Romani peoples", the term which can apply to all Romani groups, including but not limited to "Roma" and "Sinti"; Márton Rövid, "Cosmopolitanism and Exclusion: On the Limits Transnational Democracy in the Light of the Case of Roma," PhD diss. (Budapest: Central European University, 2011), 48.

${ }^{33}$ Ian Hancock, "The Emergence of Romani as a Köné outside of India," in Scholarship and the Gypsy Struggle, ed. Thomas Acton (Hatfield, UK: The University of Hertfordshire Press, 2000), 1.

${ }^{34}$ Letizia Mancini, “Riflessioni sull'identità dei rom," Jura Gentium 8, (2010-2011), 23-29.
} 
their association with [the] invading Muslim Ottoman Empire, and their foreign ways." ${ }^{35}$ Over the following centuries, the communities developed unique languages and cultural traditions, and a way of life that set them apart from the dominant European population. Often referred to using pejorative terms such as Gypsies, Zingari, Zigeuner, Gitanos, or Cigani, their marginalized position can partly be attributed to a negative view of nomadism:

....in the superior man, nomadism enlarges the spirit, educates him to wider intuitions ... in the inferior man, like the gypsy ... it creates an instability of character, ... it distances him from permanent work and facilitates greed for other peoples' possessions and other peoples' women ... In the inferior man, nomadism destroys every notion of homeland. ${ }^{36}$

The idea that nomadism was an element of asociality became deeply rooted, and consequently, European countries adopted policies for the "sedentarization" (and forced assimilation) of Romani peoples. ${ }^{37}$ For example, Italy introduced a series of institutional measures, with Romani communities "treated as a public danger and subjected to bans throughout the Italian peninsula." 38 As in the Assyrian case, by the $19^{\text {th }}$ century, nationalist ideologies informed the view that Romani peoples represented a problem of national security. The resistance displayed by itinerant people to the "re-educational" policies ${ }^{39}$ enacted within different national contexts was subsequently linked to pseudo-scientific race theories, whereby a tendency towards crime and asociality was seen as a genetic feature of the group. As early as 1876, Cesare Lombroso, an Italian criminal anthropologist, described the Zingari (Gypsies) as a "criminal race."40

Influenced by Darwinist theory, Lombroso argued that not only was it possible to identify criminals through the use of anthropometric techniques, but that certain attributes, considered responsible for creating inferior populations among the species, were hereditary. For this reason, Lombroso "believed that deliberate selection was appropriate, to complement and fortify natural selection." ${ }^{41}$ These perceptions created a context in which genocide, later carried out by the Nazi regime in Germany and its counterparts across Europe, would be considered an acceptable measure against Romani peoples. With the introduction of the Nuremberg laws in 1935, the Jewish and Romani peoples were both identified as "enemies of the race-based state." 42

\section{Forgotten Genocides}

Seyfo (The Sword): The Assyrian Genocide

Massacres of Assyrians began in earnest in 1914, as part of preparations for the invasion of Russia and Persia at the year's end. Starting with the conscription of Christian men of military age, the Ottoman authorities ordered massacres beyond the borders of the Turkish state, consolidating an established pattern of systematic massacre aimed at eliminating the indigenous non-Muslim presence in desired territories. ${ }^{43}$ Eyewitnesses recorded the treatment of Assyrian victims; Australian members of the Dunsterforce for instance, recorded that of the approximately 80,000 Assyrians and Armenians they had encountered in the Urmiah Valley in August 1918, barely

\footnotetext{
${ }^{35}$ Carol Silverman, “Early History," Cultural Survival Quarterly 19, no. 2 (1995), 8.

${ }^{36}$ Nando Sigona and Lorenzo Monasta, Imperfect Citizenship: Research into Patterns of Racial Discrimination against Roma and Sinti in Italy, Osservazione, 2006, accessed March 13, 2016, http://www.osservazione.org/documenti/OA imperfectcitizenship.pdf, 6.

${ }^{37}$ Council of Europe, “DOSTA! Enough! Go beyond prejudice, meet the Roma!,” Council of Europe, 2014, accessed March 16, 2016, http://dosta.org/media/PREMS 45213 GBR 1490 DOSTA TOOLKIT A5.pdf.

${ }^{38}$ Isabella Clough Marinaro, "Between Surveillance and Exile: Biopolitics and the Roma in Italy," Bulletin of Italian Politics 1, no. 2 (2009), 271.

${ }^{39}$ Luca Bravi and Nando Sigona, “Educazione e Rieducazione nei Campi per 'Nomadi': Una Storia,” Studi Emigrazione 43, no. 164 (2006), 862.

${ }^{40}$ Giulia Baldini et al., Alla periferia del Mondo: Il Popolo dei rom e dei Sinti Escluso dalla Storia (Milan: Insmli \& Fondazione Franceschi, 2003), 57.

${ }^{41}$ Gabriel Cavaglion, “Was Cesare Lombroso Antisemitic?," The Journal for the Study of Antisemitism 3, no. 2 (2011), 649.

${ }^{42}$ Bársony and Daróczi, Pharrajimos: The Fate of the Roma, 1.

${ }^{43}$ See e.g. "Turkish Raid in Persia. Massacre of Christians," Evening News (Sydney, NSW: 1869-1931), August 6, 1907, 4.
} 
half reached safety in British-held Mesopotamia. ${ }^{44}$ Across the decade of genocidal destruction (1914-1924), an estimated half of the indigenous Assyrian population of the Middle East was killed. ${ }^{45}$

The Turkish authorities of the Ottoman Empire, although motivated particularly by a fervent nationalism which ideologically fed the drive for ethnic and cultural homogeneity, did not hesitate to use religion as a political tool. The Young Turks declared Jihad ${ }^{46}$ in August 1914 and transformed the already existing practice of forced conversion of women and children into official government policy. Assyrian and Armenian communities were the targets of a host of genocidal strategies which escalated over time. In addition to mass murder, these included sexual violence, forced marriage and assimilation, in conjunction with forced deportation under conditions producing large numbers of deaths. Cultural destruction was also widespread.

However, there is a great deal of complexity around the targeting of Armenians and Assyrians, including geographical variance as well as differing interpretations and orders by CUP officials and lower level bureaucrats. In addition, atrocities were committed by a wide range of perpetrators, sometimes centrally ordered, sometimes acted on by local populations within a broader context of religious and ethnic hatred. In some geographical areas, the Armenian community was specifically targeted, with Assyrians and other minorities afforded a greater level of protection, at least in theory. In other areas, Assyrians were swept up in massacres of Armenians and both communities suffered huge losses. ${ }^{47}$ For example, telegrams between the governor of Diyarbekir, Dr. Resid Pasha and Interior Minister Talaat Pasha in July 1915 indicate divergence in the orders from the most senior CUP officials and the actions on the ground, with Talaat aware from German reports "that in recent days massacres have been planned of the Armenians in the province, as well as of the other Christians without any differentiation according to sect or confession" and instructing the governor not to apply the "disciplinary and political measures adopted vis-à-vis the Armenians ... to the other Christians." 48 Taner Akçam, who has analyzed a wealth of Ottoman documentation, has explained that although Talaat demanded the killings apply only to Armenians, the massacres of all Christians in Diyarbekir continued.

Eastern parts of the Empire, astride the corridor linking Anatolia with the Caucasus and Central Asia contained large Armenian and Assyrian populations, and because these communities presented a physical obstacle to the unification of the Turks in Anatolia with the Turkic-speaking peoples in Azerbaijan and Central Asia, this geographic area became a priority target for elimination. The records of the ruling political party illustrate their perception of Christian citizens as a hostile collective ${ }^{49}$ Üngor notes that "Many historical sources including interviews with Assyrian survivors suggest that genocidal intent among the CUP elite was strongest towards the Armenians." ${ }^{50}$ Yet, even though on paper the distinction between Armenian and Assyrian people was recognized, it appears that in the minds of the bureaucracy and the Muslim Turkish population, they were often seen as one enemy. ${ }^{51}$

${ }^{44}$ Ross Lloyd, “Savige Saviour: Dunsterforce in Persia," Wartime, No. 12 (2000), 22-27.

${ }^{45}$ Gaunt, Massacres, Resistance, Protectors, 433-436.

${ }^{46}$ This was widely reported in the media at the time. See e.g. "The Sultan's Jihad," The West Australian (Perth, Western Australia), December 2, 1914, 7.

${ }^{47}$ See e.g. Edward William Charles Noel, Diary of Major Noel on Special Duty in Kurdistan (Basra: Government Press, 1919). Noel observed that "In Diarbekir itself the Syrian Jacobites were scarcely molested. Of all the Christian communities they know how best to get on with the Turks, and when the massacres were ordered they were officially excluded. In the districts, however, the Government very soon lost control of the passions they had loose (if they ever wanted to keep them in control), with the result that the Jacobites suffered there as much as anybody else." 28.

${ }^{48}$ Taner Akçam, The Young Turks' Crime Against Humanity: The Armenian Genocide and Ethnic Cleansing in the Ottoman Empire (New Jersey: Princeton University Press, 2013), 208.

${ }^{49}$ Panayiotis Diamadis, "Australia's first commissioner for refugees: The 'Call from Macedonia' and Australian Humanitarian Relief in the League of Nations," Journal of the Royal Australian Historical Society 98, no. 1 (2012), 7.

${ }^{50}$ Üngör, "Book review: Hidden Genocides'," 102.

${ }^{51}$ Ronald Grigor Suny, "They Can Live in the Desert but Nowhere Else": A History of the Armenian Genocide (Princeton: Princeton University Press, 2015), 115-116. 
Baro Porrajmos (The Great Devouring): The Romani Genocide

The history of the Romani diaspora across Europe has been characterized by centuries of persecution, which reached its climax under the Nazi Fascist regimes. The vision of creating a pure nation, free from ethnic or other minority influences was embedded in Nazi doctrine, with 500,000 German Jews the earliest victims.

The Romani population in Germany numbered between 20,000 and 26,000 at the start of the Second World War, and this small number, as well as their marginality in social and economic affairs $^{52}$ meant they were not a high priority for the Nazis. But the goal of creating a "pure" nation was deeply embedded in the Nazi regime and in July 1933, a new law introduced the compulsory sterilization of those labeled as hereditary ill, applying predominantly to Romanies.

This law triggered a massive hunt for asocials (such as homeless and beggars), leading to the intensification of measures directed at destroying "organizations and subcultures considered to be breeding-grounds of immorality and deviance." 53 Policies against Romanies, in particular, escalated over the course of the war, and many thousands were imprisoned in concentration camps, or murdered by bullets and in gas chambers. Countless more were forcibly sterilized in order to rip apart the biological and social fabric of the community. Although there are no precise figures regarding the number of victims, between 500,000 and 1.5 million Romanies lost their lives during the Second World War. ${ }^{54}$

To note that the Romani Genocide has been neglected in historical study is not to suggest it is equivalent to the Holocaust of the Jews. As Michael Stewart has noted, "'The Gypsy problem' occupied a totally different place in Nazi ideology that than of 'the Jewish problem.'”55 Jews were undoubtedly considered the ultimate enemy of the Nazis, to be totally wiped out wherever they dared live. ${ }^{56}$ According to the Task Force for International Cooperation on Holocaust Education, Remembrance, and Research, ${ }^{57}$ this totality of ideology and implementation distinguishes the treatment of Jews from other examples of mass murder committed by the Nazis. So called "community aliens" ${ }^{58}$ were not all treated the same way, and "different policies hit different groups at different times." ${ }^{59}$ By the mid-1930s, Romanies had come to be viewed as "a racial, rather than social threat" ${ }^{\prime 60}$ and the intention to eliminate them from German society became manifest.

Since the end of the war, academic and public attention has been primarily focused on the Holocaust of the Jews, with the fate of Romanies considered a marginal issue. ${ }^{61}$ According to Kenrick, "in the many books written describing the Nazi period and the persecution of the Jews, Gypsies usually appear as a footnote or small section." ${ }^{62}$ When reference is made to Romanies, they are usually grouped together under the category "other non-Jewish victims." ${ }^{63}$ Because of this lack of recognition, and to emphasize the specific character of their own tragedy, Romani

\footnotetext{
${ }^{52}$ Nikolaus Wachsmann, “The Policy of Exclusion: Repression in the Nazi State, 1933-1939," in Short Oxford History of Germany: The Third Reich, ed. Jane Caplan (Oxford: Oxford University Press, 2008), 142.

${ }^{53}$ Ibid., 125

${ }^{54}$ Commissione Diritti Umani del Senato, “Rapporto conclusivo dell'indagine sulla condizione di Rom, Sinti e Camminanti in Italia," Senato della Repubblica, 2011, accessed March 1, 2016, http://www.senato.it/documenti/ repository/commissioni/dirittiumani16/Rapporto $\% 20$ conclusivo $\% 20$ indagine $\% 20$ rom, $\% 20$ sinti $\% 20 \mathrm{e} \% 20$ caminanti.pdf.

${ }^{55}$ Stewart, "The Gypsy Problem," 147.

${ }^{56}$ Wachsmann, "The Policy of Exclusion," 128; see also Saul Friedländer, Nazi Germany and The Jews: The Years of Persecution: 1933-1939, (New York: Harper Collins, 2009); and Saul Friedländer, The Years of Extermination: Nazi Germany and the Jews, 1939-1945, (New York: Harper Perennial, 2008).

${ }^{57}$ Task Force for International Cooperation on Holocaust Education, Remembrance, and Research, "2010 Education Working Group Paper," 10.

${ }^{58}$ These could be divided in three major categories: "political opponents (especially those on the left), social outcasts (those labelled as deviant), and 'racial aliens' (above all Jews)". See Wachsmann, "The Policy of Exclusion," 123.

${ }^{59}$ Ibid., 128.

${ }^{60}$ Ibid., 142.

${ }^{61}$ Hancock, "Romanies and the Holocaust," 394.

${ }^{62}$ Donald Kenrick, The A to Z of the Gypsies (Romanies), No. 135 (Lanham: Rowman \& Littlefield, 2010), xli.

${ }^{63}$ Ian Hancock, "On the Interpretation of a Word: 'Porrajmos' as Holocaust," in Travellers, Gypsies, Roma: The Demonisation of Difference, eds. Michael Hayes and Thomas Acton (Newcastle: Cambridge Scholars Press, 2006), 53.
} 
scholars introduced the concept Baro Porrajmos, or the "great devouring" of human life, to refer to the Romani Genocide. ${ }^{64}$

\section{Aftermath of the Genocides \\ Assyrian Aftermath}

The 1920 Treaty of Sevres gave hope to the surviving Assyrians scattered across British Iraq, Persia and French Syria ${ }^{65}$ by offering "a scheme of local autonomy for the predominantly Kurdish areas ... [with] full safeguards for the protection of the Assyro-Chaldeans and other racial or religious minorities within these areas." ${ }^{\prime 66}$ However, often conflicting political interests of London, Paris, Rome and Moscow combined with the 1919 revolution led by Mustafa Kemal, ${ }^{67}$ ensured the Assyrian claim for autonomy, guaranteed by the League of Nations and the Great Powers, never materialized. In addition, the small size of the Assyrian population, itself a direct result of the genocide, was used as justification for the denial of an autonomous homeland for Assyrians on their ancient territory. The major consequence of the failure of Sevres was that systematic killing of the region's Christian minorities went on for years, culminating in the destruction of Smyrne (Izmir) in September 1922. Despite the fact that persecution and indeed mass killings continued after the end of the First World War and well into the republican era, in terms of mobilizing Western engagement with Turkey in the decades after the war, there may have been a broad political benefit in relegating the Armenian Genocide to the Ottoman era and creating a distinction between that time and the new Turkish state. This may partly explain why Western countries allowed the genocides of Assyrians and other Christian minorities to fade from collective memory.

Cultural destruction and denial continued also, as the new national governments under whose jurisdiction many Assyrian communities fell, claimed Assyrian land and cultural material as state property, and changed the names of Assyrian villages and even the names of Assyrian citizens. ${ }^{68}$ These concrete actions were presented as proof that no indigenous Assyrian population had lived in the lands which were now part of these newly established nation-states.

While Assyrians had been subsumed within the category of the Ermeni milliyet before the genocide, the hiddenness of Assyrian identity continued in its aftermath. The 1923 Treaty of Lausanne did not include special protections for Assyrians, nor did it even record the Assyrians as an official minority group. When the governments of Iraq and Turkey replaced the Assyrian category in the census with broader categories of "Christian Kurds, Turks and Arabs," ${ }^{69}$ the result was that Assyrians would never be recognized as a distinct group with unique religious, ethnic and national characteristics. These developments set the stage for decades of inaccurate descriptions of Assyrians as "Turco-Semites", "Christian Kurds", and "Semitic" or "Mountain Turks."70 Not only had enormous physical losses been suffered, but the Assyrian right to its indigenous homeland, even to its very identity and presence was intentionally disappeared. As Travis has written: "So thorough has been the cultural and physical annihilation of the Assyrian people that even the memory of their distinctiveness is at risk." ${ }^{71}$

In addition, the pre-genocide Ottoman practice of categorizing people by their religious affiliation (for example, Nestorian or Church of the East, Chaldean, Eastern Catholic, or Syrian)

\footnotetext{
${ }^{64}$ Ibid., 53.

${ }^{65}$ Nicholas Awde, Nineb Lamassu, and Nicholas Al-Jeloo, Aramaic (Assyrian/Syriac) Dictionary and Phrasebook (New York: Hippocrene Books, 2007), 11.

66 “The Treaty of Sèvres, 1920 Section I, Articles 1-260," WWI Document Archive, May 20, 2009, accessed March 14, 2016, http://wwi.lib.byu.edu/index.php/Section_I, Articles 1 - 260.

${ }^{67}$ A. E. Montgomery, "The Making of the Treaty of Sèvres of 10 August 1920," The Historical Journal, 15, no. 4 (December 1972), 775-787.

${ }^{68}$ Travis, “The Assyrian Genocide," 133.

${ }^{69}$ Ibid., 133.

${ }^{70}$ Jan Pacal, "What happened to the Turkish Assyrians?," Turkish Daily News, August 29, 1996, accessed March 14, 2016, http://www.aina.org/articles/turkish.htm; Nigar Karimova and Edward Deverell, "Minorities in Turkey," Utrikespolitiska Institutet, Occasional Papers No. 19, 2001.

${ }^{71}$ Travis, "The Assyrian Genocide," 123.
} 
continued in a deliberate attempt to blur Assyrian identity and deny the genocide. The long-term impact of this has been a lack of academic scholarship on, and public or official recognition of, the Assyrian Genocide. ${ }^{72}$

\section{Romani Aftermath}

There are several parallels in elements of the aftermath of the Romani Genocide with those identified in the Assyrian case. Firstly, and crucially, is the issue of group identity. The Romanies were viewed as a social group, although their treatment under the Nazi regime comprised elements of racial ideologies that attributed to them a genetic tendency towards criminality. ${ }^{73}$ The actions taken against Romani communities were either dismissed or excused in a postwar environment that continued to persecute Romanies based on the very same stereotypes that fueled the genocide in the first place. The Third Reich policies against the Romanies were commonly regarded as control over criminals, a form of genocide denial that not only diminished the experiences of the group and misconstrued the motivations behind their persecution, but then blamed the victims for their own suffering.

Any attempts to seek recognition placed Romani survivors in a position where the same prejudices were unleashed. In a continuation of the discrimination they had faced for decades, many Romani survivors were excluded from official compensation processes, by requiring applicants to prove a fixed address and employment. ${ }^{74}$ Romani survivors who claimed compensation for incarceration in concentration camps or for forced sterilization were often told they had deserved the treatment they received. Some claiming compensation for physical and psychological effects were even examined by doctors who had been involved in the Nazi machinery. ${ }^{75}$ With Germany determining that actions taken against Romanies before 1943 were "legitimate official measures against persons committing criminal acts, not the result of policy driven by racial prejudice," ${ }^{176}$ the notion that the treatment of Romanies had been justified set the precedent for ongoing denial of their right to recognition.

This attitude was further exacerbated by the nature of the surviving Romani populations, who were, like the Assyrians, scattered across national borders, diverse, and without a central authority or national government to advocate on behalf of the community. While a process for reparations for Jewish victims was established in the decades following the end of the war, and a small number of perpetrators brought to justice via the Nuremburg Trials, Romanies were excluded from any justice-seeking processes. In addition, and in contrast with the many Jews who migrated to America, Israel, Australia and elsewhere, Romanies generally remained in the countries they had been persecuted in during the war, and subjected to the same kinds of discrimination as before. Now though, they faced the additional trauma of "a concerted effort across Europe to deny the Porrajmos." 77 Alternatively, where it was acknowledged, Romani experiences were subsumed within the category of "non-Jewish victims", which obscured the genocide simply by not naming its victims. If it was considered at all, the fate of the Romanies was viewed as a marginal issue. As Stewart has written "...the mass murder and sterilization of the Roma, Sinte, and Gypsies provides, perhaps, the locus classicus in the modern world of a genocidal catastrophe denied and cast into public oblivion." 78

\footnotetext{
${ }^{72}$ This practice of religious categorization continues to this day. For more information, see Blair Baggott, "History as a Weapon: The use of Historiography as a Tool to Justify Political Positions in Regards to the Recognition of the Assyrian Genocide," Assyrian Universal Alliance, August 10, 2014, accessed March 14, 2016, http://aua.net.au/wpcontent/uploads/2014/11/Commemoration-Of-The-Assyrian-Martyrs-And-Genocide-Day.-10th-August-2014.pdf.

${ }^{73}$ Clough Marinaro, "Between Surveillance and Exile", 272.

${ }^{74}$ Stewart, "The Gypsy Problem," 144.

${ }^{75}$ Ibid., 143.

${ }^{76}$ Katharine Quarmby, No Place to Call Home: Inside the Real Lives of Gypsies and Travellers (London: Oneworld Publications, 2013), 35

${ }^{77}$ Robbie McVeigh, "Ethnicity Denial and Racism: The Case of the Government of Ireland Against Irish Travellers," Translocations 2, no. 1 (2007), 102.

${ }^{78}$ Stewart, "The Gypsy Problem," 140
} 


\section{Academic Research and International Law}

\section{Assyrian Genocide}

While the Armenian Genocide has been recognized by an overwhelming proportion of genocide scholars and is now situated within the standard canon of twentieth century genocides, very little scholarly literature has been produced on the Assyrian Genocide. In part this is the result of the complexity of the religious, cultural, ethnic and national make-up of Assyrian identity which comprises a range of sub-groups and religious denominations, as well as the application of various exonyms (identities and definitions imposed on the community by others), spreading confusion. Partly the lack of scholarly attention paid to the Assyrian genocide is an inadvertent side-effect of the inaccessibility of much of the evidence. In addition to Turkish authorities deliberately withholding evidence, documents that are available often appear in a range of languages, most of them not widely understood. ${ }^{79}$ Another important reason that the Assyrian Genocide has remained in the shadows is the previous emphasis on proof of perpetrator intent. Relative to evidence of the Armenian Genocide, proof of intent to eradicate the Assyrian population took longer to discover and decipher. As already mentioned, much official perpetrator documentation names the Armenian community as the primary group for elimination, though in practice Assyrians were frequently targeted.

Racho Donef pioneered research into official documents indicating genocidal intent against Assyrians by analyzing telegrams sent in 1914 and 1915 by the Ministry of the Interior, mostly to the governors of the southern and eastern Ottoman provinces of Van, Mosul, Diyarbakir, Mamuretu'1 Aziz, Halep (Aleppo) and Bitlis. These demonstrate that all Assyrians, regardless of denomination, were to be "deported" and "resettled", ${ }^{80}$ terms usually used as euphemisms for genocide.

Like Armenians, thousands of Assyrians died of starvation, thirst, exposure, disease and local violence, in desert camps and along the deportation routes, aligning with articles (b) "causing bodily or mental harm"; (c) "deliberately inflicting on the [victim] group conditions of life calculated to bring about its physical destruction"; and (d) "imposing measures intended to prevent births" of the Genocide Convention. ${ }^{81}$

The emphasis on mass murder in early genocide historiography tended to overshadow other components of genocide such as deportation and forced removal and assimilation of women and children. As a result of academic research as well as efforts by respected legal scholars, cultural and biological strategies have been proven to have represented government policy, and to have constituted genocide in the Armenian case. There is extensive evidence to demonstrate government intent to eliminate the Armenian identity via forced assimilation in addition to massacres and deportation. ${ }^{82}$ While there was some divergence between the treatment of Armenians and Assyrians, the recognition of forced assimilation in the Armenian case provides a basis for acknowledging its effects on Assyrians also.

Over the last two decades, the Assyrian experience has begun to be included in academic conferences ${ }^{83}$ and works specifically examining the Assyrian Genocide have been published. ${ }^{84}$ Assyrian diaspora organizations have also increased their research output and advocacy campaigns. In addition, genocide scholars have begun to incorporate the Assyrian Genocide into journal articles and book chapters, with summaries of the Ottoman era now

\footnotetext{
${ }^{79}$ Travis, "The Assyrian Genocide," 135.

${ }^{80}$ Racho Donef, "1915: The Deportation of the Assyrians in Ottoman Documents," Atour, March 6, 2004, accessed March 14, 2016, http://www.atour.com/ aahgn/news/20040306b.html.

${ }^{81}$ United Nations, Convention on the Prevention and Punishment of the Crime of Genocide, December 9, 1948 (UN Doc. A/ $\mathrm{RES} / 3 / 260$ ).

${ }^{82}$ Akçam, The Young Turks' Crime, 290.

${ }^{83}$ See e.g., Panayiotis Diamadis, "To Deny or to Gloat: That is the Question", Paper Presentation, Portraits of Christian Asia Minor International Conference in Sydney, Australia, Published in ITNetwork, Volume 14, Issue 2 Volume 15, Issue 2 Centre for Comparative Genocide Studies, Division of Humanities, Department of Politics, Macquarie University, 1999, 29-30.

${ }^{84}$ See Gaunt, Massacres, Resistance, Protectors; Fuat Deniz, “En Minoritets Odyssé: upprätthållande och transformation av etnisk identitet i förhållande till moderniseringsprocesser: det assyriska exemplet" (Ph.D. thesis, Uppsala University, 1999); Travis, "Native Christians Massacred"; Donef, Massacres and Deportation.
} 
often noting Armenians, Assyrians and Greeks as victims of displacement and genocide. Adam Jones' Genocide: A Comprehensive Introduction, for instance, states that "while the events of the 1914-22 period have long been depicted in terms of the Armenian Genocide and its aftermath, one is justified in portraying it instead as a unified campaign against all the empire's Christian minorities". ${ }^{85}$

This view is reflected in an Assyrian saying that refers to the attitudes of the perpetrators: "An onion is an onion, red or white. All must be chopped." ${ }^{86}$ However, this grouping of victims comes with its own issues, such as the risk that the nuances of each case can be overlooked. Combining all Christian minorities together as victims of the Young Turks can overstate the role of religion in the genocides, and dilute the ethnic, cultural and national aspects of ideologies that informed the treatment of the Armenian community in particular. It can also obscure other specifics, such as the numbers of victims and survivors. It is recorded that two million indigenous Christian Armenians, Assyrians and Hellenes were massacred, deported or forcibly converted to Islam by $1918,{ }^{87}$ but these sorts of collective statistics fail to differentiate between the communities' respective losses.

The other consequence is that those Assyrians who are experiencing persecution today in Iraq and Syria, are consistently subsumed within the category of "Christian minorities", which, while recognizing the religious character of the community, overlooks their unique cultural, national and ethnic characteristics.

\section{Romani Genocide}

As in the Assyrian case, a lack of documentary evidence has contributed to the hiddenness of the Romani Genocide. While the Nazis meticulously documented the murder of Jews, their accounting of Romani deaths was deficient. The Romani population was considered to be so marginal, in fact, that their elimination did not require any written authorization. ${ }^{88}$ Once again, the emphasis on written government intent placed Romani experiences on the fringes of early academic research on genocide.

Survivor testimonies are also rare. In Romani cultures, history itself is an alien concept, especially when it is related to the commemoration of death, both individual and collective. ${ }^{89}$ Therefore, Romani survivors were "traditionally not disposed to keeping alive the terrible memories from their history." ${ }^{\prime 0}$ The orally-based nature of Romani culture and a disinclination to record events in writing meant that Romani survivor experiences have not been recorded or studied in depth. As stated by Zoltan Barany, "unlike the Jews and other victims of the Holocaust, many of whom were highly educated, Gypsy survivors did not leave behind diaries, did not write memoirs, and did not do subsequent research into this subject." ${ }^{\prime 11}$ In addition to cultural influences, those survivors reintegrating into their countries of origin, such as Germany and Italy, were faced

\footnotetext{
${ }^{85}$ Adam Jones, Genocide: A Comprehensive Introduction (New York: Routledge, 2010), 150.

${ }^{86}$ Varak Ketsemanian, "Remembering the Assyrian Genocide: An Interview with Sabri Atman," The Armenian Weekly, January 8, 2014, accessed March 14, 2016, http://armenianweekly.com/2014/01/08/remembering-the-assyrian-genocidean-interview-with-sabri-atman/.

${ }^{87}$ Estimates vary as the Turkish state did not keep records. See Jeff Benvenuto and John Lim, "The Genocide of Ottoman Greeks, 1914-1923," Rutgers Center for the Study of Genocide and Human Rights, 2013, accessed August 3, 2016, http://www.ncas.rutgers.edu/center-study-genocide-conflict-resolution-and-human-rights/genocide-ottomangreeks-1914-1923; Jeff Benvenuto, Rachel Jacobs and John Lim, “The Assyrian Genocide, 1914 to 1923 and 1933 Up to the Present," Rutgers Center for the Study of Genocide and Human Rights, 2013, accessed August 3, 2016, http://www. ncas.rutgers.edu/center-study-genocide-conflict-resolution-and-human-rights/assyrian-genocide. Comparing the problematic Ottoman census of 1912 with the survivors documented by the League of Nations in Hellas (1.4.million), and other agencies in Syria and the Soviet Union, and taking into account natural rates of birth and death, the fates of between two and three million men, women and children remain unaccounted for. On forced assimilation see Panayiotis Diamadis, "Children and Genocide," in Genocide Perspectives IV: Essays on Holocaust and Genocide, ed. Colin Tatz (Sydney: Sydney University Press, 2012); Akçam, The Young Turks' Crime.

${ }^{88}$ Zoltan Barany, The East European Gypsies: Regime Change, Marginality, and Ethnopolitics (Cambridge: Cambridge University Press, 2002), 103.

${ }^{89}$ Ibid., 103.

${ }^{90}$ Hancock, "Responses to the Porrajmos," 138.

${ }^{91}$ Barany, The East European Gypsies, 103.
} 
with enormous pressure to remain silent about their experiences, or, as already noted, blamed for their own imprisonment and oppression.

Yet another parallel with the hiddenness of the Assyrian Genocide is the impact of narrow definitions of victim groups and unrealistic expectations concerning the explicitness of evidence of perpetrator intent. The definition of victim groups under the Genocide Convention may be read as excluding Romanies, since they were assumed to have been targeted not as a racial, ethnic, national or religious group, but rather as a result of their 'asociality.' This stereotype however was founded on pseudo-biological racial theories, which attributed supposed criminal tendencies to hereditary characteristics, thought to be innate to Romanies as a group. Despite the fact that Romanies were targeted based on racial ideologies, early genocide scholars tended to accept the exclusion of Romanies from the definition of genocide victims, ${ }^{92}$ effectively sidelining their experiences. As Robbie McVeigh has explained, "if they are not an ethnic group ipso facto they cannot have experienced genocide." ${ }^{\prime 3}$

Although Raphael Lemkin's original conception of genocide included biological and cultural methods of genocide, when the Genocide Convention was ratified after the Second World War, attention was focused, understandably, on mass murder, gas chambers, ghettos and concentration camps. Genocidal tools that veered from these very overt and visible measures were discounted, and the unprecedented and industrial-scale methods used during the Holocaust became the benchmark for genocide. Although many Romanies were murdered by the Nazi regime, forced sterilization was a primary genocidal strategy against the Romani population, sometimes carried out in local "hereditary health clinics" 94 and often unrecorded. Much like forced assimilation of Assyrian women and children, forced sterilization was a tactic that remained largely unacknowledged as a genocidal tool, despite technically qualifying as a strategy of genocide under the Genocide Convention..$^{95}$

Mirroring another of the reasons for the lack of attention on the Assyrian Genocide was a heavy emphasis on clear proof of central and premeditated intent to eradicate a group. The treatment of Romani communities was not conducted in a particularly strategic way and although documents were produced indicating intent, ${ }^{96}$ sometimes decisions were made for pragmatic rather than ideological reasons, such as in the case of establishing and liquidating the "Gypsy camp" at Auschwitz. ${ }^{97}$ The lack of evidence of a single decision by authorities to eradicate the Romani population has been misinterpreted to mean there was no genocidal policy in place at the time.

A contemporary understanding of genocide allows for some divergence in implementation, recognizing that genocide rarely stems from one decision made and documented by authorities, but more often progresses over time, and frequently in response to other wartime developments. Legally, genocidal intent can be inferred from a coordinated set of actions, ${ }^{98}$ a fact that sheds new

${ }^{92}$ For more on this, see Hancock, "Downplaying the Porrajmos".

${ }^{93}$ McVeigh, "Ethnicity Denial and Racism," 101.

${ }^{94}$ Stewart, "The Gypsy Problem," 151.

${ }^{95}$ Forced sterilization of Romani women continued after the end of the war, particularly in eastern Europe during the Communist era. This represented a widespread governmental practice which lingered in some areas even after the fall of the Iron Curtain. Although forced sterilization today affects women in many parts of the world, its continuing use against Romani women indicates that the relative paucity of interest in the Romani Genocide may have allowed practices which formed part of the genocide to continue in subsequent years. See Galya Stoyanova, "Forced sterilization of Romani Women-A Persisting Human Rights Violation," Romedia Foundation, February 7, 2013, accessed June 21, 2016, https://romediafoundation.wordpress.com/2013/02/07/forced-sterilization-of-romaniwomen-a-persisting-human-rights-violation/; Open Society Foundations, "Against Her Will: Forced and Coerced Sterilization of Women Worldwide", Open Society Foundations, October 4, 2011, accessed August 3, 2016, https://www. opensocietyfoundations.org/sites/default/files/against-her-will-20111003.pdf.

${ }^{96}$ For example, Himmler's April 1942 directive to "treat gypsies as the Jews;" Gilad Margalit, Germany and its Gypsies: A Post-Auschwitz ordeal (Madison: University of Wisconsin Press, 2002), 47.

${ }^{97}$ Stewart, "The Gypsy Problem," 153.

${ }^{98}$ For example, in the context of the Armenian case, Geoffrey Robertson QC explains that "...the court must look to see whether there has been 'a pattern of purposeful action' from which a genocidal intent may be deduced - and it is precisely that pattern of CUP action... from which the CUP's guilty intention may be deduced," An Inconvenient Genocide: Who Now Remembers the Armenians? (Sydney: Vintage, 2014), 108. 
light on the Romani Genocide, during which persecution and massacres were carried out at a grassroots level by a range of perpetrators and across national borders, from Serbia and Croatia, to Italy and Romania, as well as, of course, Germany. But these were not always explicitly directed by the Nazis. The Romani Genocide was a prime example of structuralism, where local governments, low-level bureaucrats, schools and other local institutions all worked to implement a system of discrimination, persecution and eventually genocide. In some places, "municipal camps" were set up in order to concentrate Romani communities, where they were examined by scientists searching for the gene of asocial behavior. ${ }^{99}$ Local perpetrators operated in a culture where social and racial hatred was condoned and encouraged, and they were well aware that they could act with impunity. Yet in the aftermath of the Holocaust, this method of implementation did not align with the notion of genocide requiring state-sponsorship or official directions from a central authority.

\section{Public Memory}

Assyrian Monuments and Commemoration

Commemoration ceremonies dedicated to the Assyrian Genocide have largely been restricted to Assyrian diaspora communities. In recent years, commemoration of the Armenian Genocide has attracted increased attention, particularly around advocacy for recognition from the Turkish state. High profile speakers such as the eminent Geoffrey Robertson QC, who has become an ambassador for Armenian Genocide recognition, and events including the one hundred-year anniversary of the commencement of the genocide (April 24, 2015) have resulted in mainstream media coverage. Meanwhile, official acknowledgments by the Vatican, the European Union and various nations including the Ottoman Empire's then-ally, Germany, have created a sense of credibility and urgency around the Armenian Genocide, as well as broader public knowledge of its occurrence. In Australia, the connections between the Armenian Genocide and the experiences of the Anzacs in Turkey have begun to enter the collective consciousness. ${ }^{100}$ The Assyrian Genocide, however, remains beyond the awareness of the general public and attracts little coverage outside of the Assyrian press.

A host of monuments exists to officially memorialize the Armenian Genocide and some of these also recognize the Assyrian and Hellenic experiences. ${ }^{101}$ The establishment of such memorials has not, however, been simple to achieve or free from controversy. For instance, much debate surrounded the erection of a monument in Sydney specifically dedicated to Assyrian victims, ${ }^{102}$ with some local Turkish groups attempting to prevent the memorial. The plaque has been subjected to several attacks and acts of vandalism since being erected. ${ }^{103}$

In addition, sometimes the positive impact of public memorials is diminished by continuing confusion concerning Assyrian identity, and debate over how to recognize the religious diversity within the community. It is arguable that ongoing theological, political and jurisdictional disputes amongst the adherents of the different Assyrian churches are hampering the cause of public and political recognition of the genocide. The Church of the East ("Nestorian") and sections of the Syriac Orthodox ("Jacobite") churches commemorate the "Assyrian Genocide." Some recent monuments have, in response to the assertion by the Vatican-aligned Chaldean Catholic Church of the existence of a "Chaldean Genocide", begun to distinguish between religious denominations in public memorials, such as one located in Belgium. ${ }^{104}$ A memorial unveiled in Sweden in May

\footnotetext{
${ }^{99}$ Stewart, "The Gypsy Problem," 151.

${ }^{100}$ See e.g. Peter Stanley and Vicken Babkenian, Armenia, Australia and the Great War (Sydney: New South Publishing, 2016).

${ }^{101}$ For example, Monument Australia, "Hellenic, Armenian and Assyrian Genocides Monument," Monument Australia, 2016, accessed March 15, 2016, http://monumentaustralia.org.au/themes/conflict/genocide/display/97793-hellenic\%2Carmenian-and-assyrian-genocides; Monument Australia, "Assyrian Genocide Monument," Monument Australia, 2016, accessed March 15, 2016, http://monumentaustralia.org.au/themes/conflict/genocide/display/93083-assyrian-genocidemonument.

${ }^{102}$ Ibid.

${ }^{103}$ Most recently, it was defaced in April 2015, Kate Aubusson, "Assyrian Memorial in Bonnyrigg Vandalized," The Sydney Morning Herald, April 16, 2015, accessed March 22, 2016, http://www.smh.com.au/nsw/assyrian-memorial-inbonnyrigg-vandalised-20150416-1mmvgt.html.

${ }^{104}$ Abdulmesih BarAbraham and Miryam Abraham, "The Assyrian Genocide Monument in Belgium," Assyrian International News Agency, August 9, 2013, accessed March 15, 2016, http://www.aina.org/news/2013089120251.htm.
} 
2015 complicates efforts to bring the Assyrian experience out of its current state of hiddenness, by referring to the "Centenary of the Genocides of the Armenians, Assyrians, Syriacs, Chaldeans and Hellenes." Similarly, the "Oecumenical Memorial" in Berlin, Germany, identifies the victim populations as "Armenians, Hellenes of Asia Minor, Pontus and eastern Thrace, and Arameans (Syriacs, Assyrians, Chaldeans)." ${ }^{105}$ It comprises a set of four elaborate memorials along a wall, creating three separate spaces for each group as well as one, common space.

While these memorials are undoubtedly well intentioned, they serve to maintain historical factions and divisions that were established under the Ottoman Empire and even earlier, and to ensure the Assyrian Genocide remains misunderstood or simply ignored by the general public.

\section{Romani Monuments and Commemoration}

It was not until the 1970s that an important shift occurred in the acknowledgement and memorialization of Romani experiences during the Nazi era. Alongside civil rights movements and a growing body of scholarly literature, Romanies began to push for greater attention to be paid to their experience of genocide. ${ }^{106} \mathrm{~A}$ small, albeit increasing, body of literature now focuses on the genocide of the Romanies in Germany and other European states that were part of the Axis during the Second World War. ${ }^{107}$ Still today though, Romanies "seldom appear in official statistics and Holocaust victim commemoration events." 108 And as Hancock maintains, there is still "a long way to go both with our understanding of the Porrajmos and with achieving its proper acknowledgement in the classroom." ${ }^{109}$ The task of recognition is complicated by the fact that, like the Assyrians, the Romanies constitute an internally diverse group, characterized by cultural fragmentation as well as factional rivalries, which has prevented the possibility of empowerment around common social, cultural and political goals. ${ }^{110}$

In Italy, the Porrajmos remains highly under-studied and the memory of the Romanies' past is still not officially recognized. Indeed, its very reality continues to be questioned. Historical investigation of the persecution and internment of Italian Romanies has been carried out only by independent researchers and only since around 1999. An increase in national patriotism is now playing a key role in the emergence of an historical amnesia and revisionism which is allowing racism to re-emerge, together with the myth of Italian kindness and moral superiority. ${ }^{111}$

In Germany, on the contrary, Italy's principal partner in the Axis alliance, this recognition arrived in 1982 under then chancellor Helmut Kohl. More recently, on Holocaust Memorial Day in 2011, Zoni Weisz became the first Romani survivor to address the German Parliament, ${ }^{112}$ and the following year, Chancellor Angela Merkel inaugurated a monument dedicated to Sinti and Roma victims. ${ }^{113}$ In those countries where local populations collaborated with the Nazis and perpetrated

${ }^{105}$ For a visual depiction of the monument plans, see FÖGG, "Konzept der Gedenkstaette", FÖGG, accessed March 15, 2016, http://www.genozid-gedenkstaette.de/gedenkstaette/Mahnmal-Konzep-2015.pdf.

${ }^{106}$ Symi Rom-Rymer, "Roma in the Holocaust," Moment, July/August, 2011, accessed March 15, 2016, http://www. momentmag.com/roma-in-the-holocaust/.

107 Michelle Kelso, "'And Roma were Victims, too' The Romani Genocide and Holocaust Education in Romania," Intercultural Education 24, no. 1-2 (2013): 61-78; Gilad Margalit, Germany and its Gypsies; Zoltán Vági, László Csősz and Gábor Kádár, The Holocaust in Hungary: Evolution of a Genocide (Lanham: AltaMira Press, 2013).

${ }^{108}$ European Commission, "EU Projects in Favour of the Roma Community. Exhibition Catalogue. Education, Culture, Youth Best Practices", EUROPA, March, 2010, accessed March 14, 2016, http://bookshop.europa.eu/en/eu-projects-infavour-of-the-roma-community-pbNC8010213/;pgid=Iq1Ekni0.11SR0OOK4MycO9B0000F Iix6ef;sid=KuQjploCbS8jrg zkGci9ATgniCdf9hdhNIY=, p. 10.

${ }^{109}$ Hancock, "Romanies and the Holocaust," 394.

${ }^{110}$ Boscoboinik, "Challenging Borders", 187.

${ }^{111}$ Riccardo Armillei, "The Institutional Concealment of the Romanies' Culture: The Ongoing Legacy of Fascist Italy," Social Identities: Journal for the Study of Race, Nation and Culture 22, no. 5 (2016): 503.

112 Andrew Bowen and Shant Shahrigian, "German President makes Historic Speech at Auschwitz," Deutsche Welle, January 27, 2011, accessed March 15, 2016, http://www.dw.com/en/german-president-makes-historic-speech-atauschwitz/a-14798859.

${ }^{113}$ Karoline Kuhla, "A Monument to the Porajmos: Sinti and Roma Holocaust Victims Remembered in Berlin," SPIEGEL ONLINE, October 24, 2012, accessed March 15, 2016, http://www.spiegel.de/international/germany/monument-tosinti-and-roma-murdered-in-the-holocaust-opens-in-berlin-a-863212.html. 
their own massacres of Jews and Romanies, there has been little motivation to commemorate the victims for fear of highlighting their own complicity. In Romania, despite the unveiling of a $\$ 7.4$ million Holocaust memorial to commemorate over 280,000 Jews and 11,000 Romanies who died as victims of the Ion Antonescu regime, the murder of the Romani community remains a taboo subject (as explored in the 2015 documentary film Valley of Sighs). ${ }^{114}$ Although Romanies are recognized among the victims, the context of their suffering has not been well illuminated, nor perpetrators held accountable. As Kelso and Eglitis write, "Roma are simultaneously represented, unrepresented and misrepresented in the historical story and memorial of the Holocaust in Romania."115

In Hungary, Roma and Sinti Genocide Remembrance Day is commemorated in a number of memorial events held throughout the country. In 2014, former President János Áder delivered a speech at the inauguration of a new center dedicated to Romani history, culture, education and Holocaust remembrance. Despite these steps, Romani survivors and their descendants "are not only struggling against attempts to disavow and erase the memory of what happened to them, but also against new persecutions." ${ }^{116}$ The rise of right-wing ultra-nationalism does not bode well for Porrajmos or Holocaust remembrance in Hungary.

In Bulgaria, March 10 was designated by the Council of Ministers as the "Day of the Salvation of the Bulgarian Jews and of the Victims of the Holocaust and of the Crimes against Humanity." 117 However, there is no specific statement by the Council as to whether Romanies are included as victims. In 2014, Croatia's parliament adopted August 2 as "International Roma Holocaust (Porrajmos) Remembrance Day." ${ }^{118}$ Yet, still many Croatian Romanies continue to suffer segregation and discrimination that pervades every aspect of their lives, from education to health and employment. ${ }^{119}$ As for the Slovak Republic, terms that express the Romani Genocide, such as Porrajmos or Samudaripen (mass killing) are still "not recognized and not acceptable."120

\section{Conclusion}

The parallels between Assyrian and Romani genocides having been treated as an afterthought of history, or ignored completely, are significant. What does this tell us about why some genocides are omitted from collective memory and official writing of history?

There is rarely one reason for a genocide having been forgotten. Exclusive attention on betterknown genocides that occurred simultaneously cannot be said, in and of itself, to have obscured the Assyrian and Romani cases. There is an interplay between various factors, some inadvertent and others deliberate that has resulted in the two genocides remaining on the periphery of academic and public attention. Many of these factors began even before the genocides occurred, continued throughout, and were consolidated in the aftermath of the events.

In both cases, issues such as a complex group identity that extends beyond neat ethnic, national and/or religious lines, as well as definitions imposed by others and intentional muddying of the

\footnotetext{
${ }^{114}$ Mihai Andrei Leaha, "The Last Roma Testimonies about Transnistria in the Documentary Film 'Valley of Sighs'," (paper presented at the Gypsy Lore Society Annual Meeting and Conference on Romani Studies, Chisinau, Republic of Moldova, September 10-12, 2015).

${ }^{115}$ Michelle Kelso and Daina S. Eglitis, "Holocaust commemoration in Romania: Roma and the Contested Politics of Memory and Memorialization," Journal of Genocide Research 16, no. 4 (2014), 487.

${ }^{116}$ Katalin Katz, "History and Memory: A Case Study of the Roma at the Komarom Camp in Hungary," in The Roma. A Minority in the Europe: Historical, Political and Social Perspectives, eds. Roni Stauber and Raphael Vago (Budapest-New York: Central European University Press, 2007), 70.

${ }^{117}$ Organization for Security and Co-operation in Europe, "Holocaust Memorial Days in the OSCE Region: An Overview of Governmental Practices," OSCE, 2012, accessed March 15, 2016, http://www.osce.org/odihr/135916?download=true $\underline{27}$.

${ }^{118}$ Dalje.com, “Croatia declares August 2 Roma Genocide Remembrance Day,” Dalje.com, December 12, 2014, accessed March 14, 2016, http://arhiva.dalje.com/en-croatia/croatia-declares-august-2-roma-genocide-remembrance-day/530625.

119 Amnesty International, "Amnesty International Report 2014/15: The State of the World's Human Rights," Amnesty International, 2015, accessed March 15, 2016, https://www.amnesty.org/en/documents/pol10/0001/2015/en/.

${ }^{120}$ Council of Europe, "Overview on the Recognition of the Genocide of Roma and Sinti (Pharrajimos/Samudaripen) and on the Officialization of the date of 2 August as a Commemoration day for the Victims of World War II in Member States of the Council of Europe," Council of Europe, 2013, accessed August 3, 2016, http://rm.coe.int/ CoERMPublicCommonSearchServices/DisplayDCTMContent?documentId=0900001680089824.
} 
group's identity, have contributed to an ongoing lack of clarity about what constitutes Assyrian and Romani identity, let alone the history of their genocides. Calculated strategies to hide the history of the communities and annul their identification as a group may even be said to constitute genocidal tactics in themselves. In both examples, internal divisions and the absence of a unified authority to advocate the cause of recognition continue to exacerbate this situation.

Moreover, the relative lack of official documentation, corroborating evidence and survivor testimony, compared with that available for the Holocaust and Armenian Genocide, relegated the two genocides to virtual oblivion within academia until recently. In the Assyrian case, in addition to the Turkish authorities' denial and refusal to release documentation, that evidence which is available is less accessible, requiring knowledge of many cultures, geographical areas, aspects of history, and languages. The tactics used after the war to erase Assyrian identity in official records meant that the history has not been easy to reconstruct and analyze.

The Assyrian and Romani genocides were also forgotten due to aspects of early academic study of genocide, including the focus on written evidence of perpetrator intent and on direct methods of mass murder at the expense of other genocidal strategies. Both the Assyrian and Romani genocides were committed by a range of perpetrators; varied from region to region; relied on massacre as well as cultural and biological elimination strategies; and involved large-scale deportations causing huge numbers of deaths.

Meanwhile, the narrow scope of the Genocide Convention, which provides the legal framework for genocide to this day, combined with an ongoing misperception of Romanies as a social, rather than ethnic group, effectively excluded the genocide of the Romanies from legal recognition.

Acknowledgement remains a crucial issue for today's Romanies and Assyrians. This acknowledgement does not, however, rest on equating their experiences with their better-known counterparts or blaming other communities for eclipsing their experiences and history. What is a critical progression on the path to achieving full recognition of the Assyrian and Romani genocides is a better understanding of how the process of forgetting and concealing the two genocides developed. Only once these processes are more fully understood can redress occur in academia, the law and public commemoration spaces.

\section{Bibliography}

Akçam, Taner. The Young Turks' Crime Against Humanity: The Armenian Genocide and Ethnic Cleansing in the Ottoman Empire. Princeton: Princeton University Press, 2013.

Aderet, Ofer. "Genocide Scholar Blasts Israel's "Racist' Teaching of the Holocaust", Haaretz, January 27, 2016. Accessed March 13, 2016, http://www.haaretz.com/israel-news/. premium-1.699749.

Al-Jeloo, Nicholas. "Who are the Assyrians?" Conference Paper at The Assyrian Australian Academic Society, Sydney, Australia, July 2, 2000.

----. "Assyrians: Between Homeland and Diaspora." Conference Paper at Assyrian American Cultural Organization of Arizona, Arizona State University - West Campus September 7, 2013.

Amnesty International. "Amnesty International Report 2014/15: The State of the World's Human Rights." Amnesty International, 2015. Accessed March 15, 2016, https://www.amnesty.org/ en/documents/pol10/0001/2015/en/.

Armillei, Riccardo. "The Institutional Concealment of the Romanies' Culture: The Ongoing Legacy of Fascist Italy." Social Identities: Journal for the Study of Race, Nation and Culture 22, no. 5 (2016): 502-520.

Assyrian International News Agency, "99 Years of Turkish Genocide," AINA, April 23, 2014. Accessed March 13, 2016, http://www.aina.org/releases/20140423134125.htm.

Assyrian Universal Alliance. "100 Years of Genocide, The Assyrian Nation reflects," Assyrian Universal Alliance, August 5, 2015, Accessed March 5, 2016, http://aua.net.au/wp-content/ uploads/2015/08/Media-Release-for-Centennial-Commemoration.pdf.

Aubusson, Kate. "Assyrian Memorial in Bonnyrigg Vandalized." The Sydney Morning Herald, April 16, 2015. Accessed March 22, 2016, http://www.smh.com.au/nsw/assyrian-memorial-inbonnyrigg-vandalised-20150416-1mmvgt.html. 
Awde, Nicholas, Nineb Lamassu, and Nicholas Al-Jeloo. Aramaic (Assyrian/Syriac) Dictionary and Phrasebook. New York: Hippocrene Books, 2007.

Baggott, Blair. "History as a Weapon: The Use of Historiography as a Tool to Justify Political Positions in regards to the Recognition of the Assyrian Genocide." Assyrian Universal Alliance, August 10, 2014. Accessed March 14, 2016, http://aua.net.au/wp-content/uploads/2014/11/ Commemoration-Of-The-Assyrian-Martyrs-And-Genocide-Day.-10th-August-2014.pdf.

Baldini Giluia, Baldoni Guido, D'Isola I., Frassanito Gabriele, and Sullam Mauro, eds. Alla periferia del mondo: Il popolo dei rom e dei sinti escluso dalla storia. Milan: Insmli \& Fondazione Franceschi, 2003.

BarAbraham, Abdulmesih and Miryam Abraham. "The Assyrian Genocide Monument in Belgium." Assyrian International News Agency, August 9, 2013. Accessed March 15, 2016, http://www. aina.org/news/2013089120251.htm.

Barany, Zoltan. The East European Gypsies: Regime change, Marginality, and Ethnopolitics. Cambridge, UK: The University Press, 2002.

Bársony, János, and Ágnes Daróczi, eds. "Pharrajimos: The fate of the Roma during the Holocaust." IDEA, 2008.

Benjamin, Walter. "Theses on the philosophy of history." In Illuminations, edited by Hannah Arendt, 257- 8. London: New Left Books, 1973.

Benvenuto, Jeff and Lim, John. "The Genocide of Ottoman Greeks, 1914-1923." Rutgers Center for the Study of Genocide and Human Rights, 2013. Accessed March 15, 2016, http://www. ncas.rutgers.edu/center-study-genocide-conflict-resolution-and-human-rights/genocideottoman-greeks-1914-1923.

Benvenuto, Jeff, Jacobs, Rachel and Lim, John. "The Assyrian Genocide, 1914 to 1923 and 1933 up to the present." Rutgers Center for the Study of Genocide and Human Rights, 2013. Accessed March 15, 2016, http://www.ncas.rutgers.edu/center-study-genocide-conflict-resolutionand-human-rights/assyrian-genocide-1914-1923-and-1933-pres.

Boscoboinik, Andrea, "Challenging borders and constructing boundaries: An analysis of Roma political processes." In Identity politics: Histories, Regions and Borderlands, edited by Vytis Ciubrinskas and Rimanta Sliuzinskas, 181-193. Klaipeda: Klaipeda University, 2009.

Bowen, Andrew and Shant Shahrigian. "German President Makes Historic Speech at Auschwitz." Deutsche Welle, January 27, 2011. Accessed March 15, 2016, http://www.dw.com/en/germanpresident-makes-historic-speech-at-auschwitz/a-14798859.

Bravi, Luca and Nando Sigona. "Educazione e rieducazione nei campi per 'nomadi': una storia," Studi Emigrazione 43, no. 164 (2006): 857-874.

Cavaglion, Gabriel. "Was Cesare Lombroso Antisemitic?." The Journal for the Study of Antisemitism 3, no. 2 (2011): 647-666.

Clough Marinaro, Isabella. "Between Surveillance and Exile: Biopolitics and the Roma in Italy," Bulletin of Italian Politics 1, no. 2 (2009): 265-87.

Commissione Diritti Umani del Senato. "Rapporto conclusivo dell'indagine sulla condizione di Rom, Sinti e Camminanti in Italia," Senato della Repubblica, 2011. Accessed March 1, 2016, http://www.senato.it/documenti/repository/commissioni/dirittiumani16/Rapporto\%20 conclusivo\%20indagine $\% 20 \mathrm{rom}, \% 20$ sinti $\% 20 \mathrm{e} \% 20$ caminanti.pdf.

Council of Europe. "Overview on the recognition of the genocide of Roma and Sinti (Pharrajimos / Samudaripen) and on the officialisation of the date of 2 august as a commemoration day for the victims of World War II in member states of the Council of Europe." Council of Europe, 2013. Accessed March 15, 2016, www.coe.int.

----. "DOSTA! Enough! Go beyond prejudice, meet the Roma!." Council of Europe, 2014. Accessed March 16, 2016, http://dosta.org/media/PREMS 45213 GBR 1490 DOSTA TOOLKIT A5.pdf.

Cunningham, Lawrence and John Reich. Culture and Values: a Survey of the Humanities. Boston: Cengage Learning, 2009.

Dalje.com. "Croatia declares August 2 Roma Genocide Remembrance Day". Dalje.com, December 12, 2014. Accessed March 14, 2016, http://arhiva.dalje.com/en-croatia/croatia-declaresaugust-2-roma-genocide-remembrance-day/530625. 
Diamadis, Panayiotis. "Australia's first commissioner for refugees: the 'call from Macedonia' and Australian humanitarian relief in the League of Nations," Journal of the Royal Australian Historical Society 98, no. 1 (2012): 7-27.

----. "Children and Genocide." In Genocide Perspectives IV: Essays on Holocaust and Genocide, edited by Colin Tatz, 312-52. Sydney: Sydney University Press, 2012.

Donef, Racho. "1915: The Deportation of the Assyrians in Ottoman Documents." Atour, March 6, 2004. Accessed March 14, 2016, http://www.atour.com/ aahgn/news/20040306b.html.

Donef, Racho. Massacres and Deportation of Assyrians in Northern Mesopotamia: Ethnic Cleansing by Turkey 1924-1925. Stockholm: Nsibin, 2009.

European Commission. "EU projects in favour of the Roma community. Exhibition catalogue. Education, Culture, Youth best practices." EUROPA, March, 2010. Accessed March 14, 2016,

http://bookshop.europa.eu/en/eu-projects-in-favour-of-the-romacommunity-pbNC8010213/:pgid=Iq1Ekni0.11SR0OOK4MycO9B0000F Iix6ef;sid=KuQjploCbS8jrgzkGci9ATgniCdf9hdhNJY=.

Evening News. "Turkish raid in Persia. Massacre of Christians." Evening News, August 6, 1907, page 4. Accessed September 19, 2016, http://trove.nla.gov.au/newspaper/ article $/ 112648565$ ? searchTerm=turkish\%20raid\%20in\%20persia\&searchLimits=dateFr om=1907-01-01 I I I dateTo=1907-12-31.

Faiola, Anthony. "A survivor recalls the 'forgotten genocide': the Roma," The Washington Post, February 5, 2015. Accessed March, 1, 2016, http://roma.idebate.org/news-articles/survivorrecalls-forgotten-genocide-roma.

FÖGG. "Konzept der Gedenkstaette." FÖGG. Accessed March 15, 2016, http://www.genozidgedenkstaette.de/gedenkstaette/Mahnmal-Konzep-2015.pdf.

Friedländer, Saul. Nazi Germany and The Jews: The Years of Persecution: 1933-1939. New York : HarperCollins, 1997 ----. The years of extermination: Nazi Germany and the Jews, 19391945. New York: HarperCollins: 2007.

Gaunt, David. Massacres, Resistance, Protectors: Muslim-Christian Relations in Eastern Anatolia during World War I. Piscataway: Gorgias Press; 2006.

Halbwachs, Maurice. The collective Memory. Translated by F. J. Didder Jr. and V. Yazdi Ditter. New York: Harper and Row, 1980.

Hancock, Ian. "The Emergence of Romani as a Koïné Outside of India." In Scholarship and the Gypsy Struggle, edited by Thomas Acton, 1-13. Hatfield, UK: The University of Hertfordshire Press, 2000.

----. "Downplaying the Porrajmos: The Trend to Minimize the Romani Holocaust," Journal of Genocide Research 3, no. 1 (2001): 79-85.

----. "Romanies and the Holocaust: A Re-evaluation and an Overview." In The Historiography of the Holocaust, edited by Dan Stone, 383-396. New York: Palgrave-Macmillan, 2004. http://dx.doi.org/10.1057/9780230524507 18

----. "On the Interpretation of a Word: 'Porrajmos' as Holocaust." In Travellers, Gypsies, Roma: The Demonisation of Difference, edited by Michael Hayes and Thomas Acton, 53-57. Newcastle: Cambridge Scholars' Press, 2006.

----. "Responses to the Porrajmos: The Romani Holocaust." In Is the Holocaust Unique?, edited by Alan Rosenbaum, 75-102. Boulder: The Westview Press, 2009.

Hinton, Alexander Laban, Thomas LaPointe, and Douglas Irvin-Erickson, eds. Hidden Genocides: Power, Knowledge, Memory. Newark: Rutgers University Press, 2013.

Jones, Adam. Genocide: A Comprehensive Introduction. New York: Routledge, 2010.

Karimova, Nigar and Edward Deverell. "Minorities in Turkey." Utrikespolitiska institutet, Occasional Papers no. 19 (2001): 1-24.

Katz, Katalin. "'Story.' History and Memory: a Case Study of the Roma at the Komarom Camp in Hungary." In The Roma. A Minority in the Europe: Historical, Political and Social Perspectives, edited by Roni Stauber and Raphael Vago, 69-88. Budapest-New York: CEU Press, 2007.

Kelso, Michelle. "'And Roma were victims, too.' The Romani Genocide and Holocaust Education in Romania." Intercultural Education 24, no. 1-2 (2013): 61-78. http://dx.doi.org/10.1080/146 $\underline{75986.2013 .768060}$ 
Kelso, Michelle, and Daina S. Eglitis. "Holocaust commemoration in Romania: Roma and the Contested Politics of Memory and Memorialization." Journal of Genocide Research 16, no. 4 (2014): 487-511. http://dx.doi.org/10.1080/14623528.2014.975949

Kenrick, Donald. The A to Z of the Gypsies (Romanies), No. 135. Lanham: Rowman \& Littlefield, 2010. Ketsemanian, Varak. "Remembering the Assyrian Genocide: An Interview with Sabri Atman." The Armenian Weekly, January 8, 2014. Accessed March 14, 2016, http://armenianweekly. com/2014/01/08/remembering-the-assyrian-genocide-an-interview-with-sabri-atman/.

König, Helmut. "Paradoxes of Memory." Eurozine, April 8, 2011. Accessed July 9, 2016, http://www. eurozine.com/articles/article 2011-08-04-koenig-en.html.

Kuhla Karoline. "A Monument to the Porajmos: Sinti and Roma Holocaust Victims Remembered in Berlin." SPIEGEL ONLINE, October 24, 2012. Accessed March 15, 2016, http://www.spiegel. de/international/germany/monument-to-sinti-and-roma-murdered-in-the-holocaustopens-in-berlin-a-863212.html.

Leaha, Mihai Andrei. "The last Roma testimonies about Transnistria in the Documentary Film 'Valley of Sighs."' Paper presented at the Gypsy Lore Society Annual Meeting and Conference on Romani Studies, Chisinau, Republic of Moldova, September 10-12, 2015.

Lemarchand, René, Forgotten Genocides: Oblivion, Denial, and Memory. Philadelphia: University of Pennsylvania Press, 2013.

Lloyd, Ross. "Savige Saviour: Dunsterforce in Persia." Wartime, no. 12 (2000), 22-27.

Mancini, Letizia. "Riflessioni sull'identità dei rom [Reflections on Romani identity]." Jura Gentium 8, (2010-2011), 23-29.

Margalit, Gilad. Germany and its Gypsies: A post-Auschwitz ordeal. Madison: University of Wisconsin Press, 2002.

McVeigh, Robbie. "Ethnicity Denial and Racism: The Case of the Government of Ireland Against Irish Travellers." Translocations 2, no. 1 (2007): 90-133.

Millar, Fergus. A Greek Roman Empire: power and belief under Theodosius II (408-450), Vol. 64. Berkeley: University of California Press, 2006.

Mirga, Andrzej, and Nicolae Gheorghe. "The Roma in the twenty-first century: A policy." Project on Ethnic Relations, 1997 1997. Accessed July 7, 2016, http://www.per-usa.org/1997-2007/21st c. htm.

Monument Australia. "Assyrian Genocide Monument." Monument Australia, 2016. Accessed March 15, 2016, http://monumentaustralia.org.au/themes/conflict/genocide/display/93083assyrian-genocide-monument.

-----. "Hellenic, Armenian and Assyrian Genocides Monument." Monument Australia, 2016. Accessed March 15, 2016, http://monumentaustralia.org.au/themes/conflict/genocide/ display/97793-hellenic\%2C-armenian-and-assyrian-genocides.

Moses, Dirk A. "Conceptual Blockages and Definitional Dilemmas in the 'Racial Century': Genocides of Indigenous Peoples and the Holocaust," Patterns of Prejudice 36, no. 4 (2002): 7-36. http://dx.doi.org/10.1080/003132202128811538

-----. "The Canadian Museum for Human Rights: the 'uniqueness of the Holocaust' and the question of genocide," Journal of Genocide Research 14, no. 2 (2012): 215-238. http://dx.doi. org/10.1080/14623528.2012.677762

Noel, Edward William Charles. Diary of Major Noel on Special Duty in Kurdistan. Basra: Government Press, 1919.

Open Society Foundations. "Against Her Will: Forced and Coerced Sterilization of Women Worldwide." Open Society Foundations, October, 4, 2011. Accessed June 21, https://www. opensocietyfoundations.org/sites/default/files/against-her-will-20111003.pdf.

Organization for Security and Co-operation in Europe. "Holocaust Memorial Days in the OSCE Region: An overview of governmental practices." OSCE, 2012. Accessed March 15, 2016, http://www.osce.org/odihr/135916?download=true 27.

Pacal, Jan. "What happened to the Turkish Assyrians?," Turkish Daily News, August 29, 1996. Accessed March 14, 2016, http://www.aina.org/articles/turkish.htm.

Quarmby, Katharine. No Place to Call Home: Inside the Real Lives of Gypsies and Travellers. London: Oneworld Publications, 2013. 
Robertson, Geoffrey Q.C. An Inconvenient Genocide: Who Now Remembers the Armenians? Sydney: Vintage, 2014.

Rom-Rymer, Symi. “Roma in the Holocaust." Moment, July/August, 2011. Accessed March 15, 2016, http://www.momentmag.com/roma-in-the-holocaust/.

Rövid, Márton. "Cosmopolitanism and Exclusion: On the limits transnational democracy in the light of the case of Roma," PhD dissertation. Budapest: Central European University, 2011.

Sachedina, Abdulaziz. The Islamic roots of democratic pluralism. New York: Oxford University Press, 2000.

Schull, Kent F. "Difference during the Second Constitutional period." In Religion, Ethnicity and Contested Nationhood in the Former Ottoman Space, edited by Jørgen S. Nielsen, 63-88. Leiden: Brill, 2012.

Sigona, Nando and Lorenzo Monasta. Imperfect citizenship: Research into patterns of racial discrimination against Roma and Sinti in Italy, Osservazione, 2006. Accessed March 13, 2016, http://www. osservazione.org/documenti/OA imperfectcitizenship.pdf.

Silverman, Carol. "Early History," Cultural Survival Quarterly 19, no. 2 (1995): 43-49.

Stanley, Peter and Babkenian, Vicken. Armenia, Australia and the Great War. Sydney: New South Publishing, 2016.

Stewart, Michael. "The Gypsy Problem: An Invisible Genocide." In Forgotten Genocides: Oblivion, Denial, and Memory, edited by Rene Lemarchand, 137-156. Philadelphia: University of Pennsylvania Press, 2013.

Stoyanova, Galya. "Forced sterilization of Romani women - a persisting human rights violation." Romedia Foundation, February 7, 2013. Accessed June 21, 2016, https://romediafoundation. wordpress.com/2013/02/07/forced-sterilization-of-romani-women-a-persisting-humanrights-violation/.

Suny, Ronald Grigor. "They Can Live in the Desert but Nowhere Else": A History of the Armenian Genocide. Princeton: Princeton University Press, 2015. http://dx.doi.org/10.1515/9781400865581

Task Force for International Cooperation on Holocaust Education, Remembrance, and Research. "2010 Education Working Group Paper on the Holocaust and Other Genocides," United Nations, 2010. Accessed March 16, 2016, http://www.un.org/en/holocaustremembrance/ EM/partners\%20materials/EWG Holocaust and Other Genocides.pdf.

The Times. "The Salonika Congress; The Young Turks and their Programme." The Times, October 3, 1911.

The West Australian. "The Sultan's Jihad." The West Australia, December 2, 1914. "The Treaty of Sèvres, 1920 Section I, Articles 1 - 260." WWI Document Archive, May 20, 2009. Accessed March 14, 2016, http://wwi.lib.byu.edu/index.php/Section I, Articles 1 - 260.

Townsend, Laura Shepard. "The Holocaust's Forgotten Roma Victims," MJCIMAGEWORKS, September 14, 2014. Accessed March 1，2016, http://mjcimageworks.com/blog/theholocausts-forgotten-roma-victims/.

Travis, Hannibal. "'Native Christians Massacred': The Ottoman Genocide of the Assyrians during World War I." Genocide Studies and Prevention 1, no. 3 (2006): 327-371. http://dx.doi. org/10.3138/yv54-4142-p5rn-x055

-----. "The Assyrian Genocide: A Tale of Oblivion and Denial." In Forgotten Genocides: Oblivion, Denial, and Memory, edited by Rene Lemarchand, 123-136. Philadelphia: University of Pennsylvania Press, 2013.

-----. "Constructing the 'Armenian Genocide': How Scholars Unremembered the Assyrian and Greek Genocides in the Ottoman Empire." In Hidden Genocides: Power, Knowledge, Memory, edited by Hinton, Alexander Laban, Thomas La Pointe, and Douglas Irvin-Erickson, 170-192. Newark: Rutgers University Press, 2014.

Üngör, Uğur Ümit. “The Armenian Genocide, 1915." In The Holocaust and Other Genocides: An Introduction, edited by Barbara Boender and Wichert ten Have, 45-72. Amsterdam: Amsterdam University Press, 2012.

-----. "Hidden Genocides: Power, Knowledge, Memory," Genocide Studies and Prevention: An International Journal 8, no. 3 (2014): 101-102. http://dx.doi.org/10.5038/1911-9933.8.3.9 
United Nations. "Convention on the Prevention and Punishment of the Crime of Genocide." United Nations, 1948. Accessed March 22, 2016, https://treaties.un.org/doc/Publication/UNTS/ Volume\%2078/volume-78-I-1021-English.pdf.

Vági, Zoltán, László Csősz, and Gábor Kádár. The Holocaust in Hungary: Evolution of a Genocide. Lanham: AltaMira Press, 2013.

Wachsmann, Nikolaus. "The Policy of Exclusion: Repression in the Nazi State, 1933-1939." In Short Oxford history of Germany: The Third Reich, edited by Jane Caplan, 122-145. Oxford, UK: Oxford University Press, 2008. 